\title{
ACCOUNTABILITY AND PERFORMANCE: EVIDENCE FROM LOCAL GOVERNMENT
}

\author{
Mesri Welhelmina Nisriani Manafe \\ Faculty of Economic Artha Wacana Christian University \\ (mesrimanafe@gmail.com) \\ Rusdi Akbar \\ Faculty of Economics and Business Gadjah Mada University \\ (rusydi.akbar@gmail.com)
}

\begin{abstract}
Local government accountability attracts attention since the issuance of the Presidential Instruction Number 7 of 1999 on Accountability Reporting of the Performance of Government Institutions (Instruksi Presiden No. 7 Tahun 1999 tentang Laporan Kinerja Instansi Pemerintah). In practice, this accountability is not as was expected. One indication of the causal factor of the failure of the accountability implementation program is that it is considered as an obligation to describe and to justify the behavior of the accountability actors. The objective of this study is to empirically examine the correlation between the requirements of various types of accountability with negative perception of the work context and the work performance of the accountability actors. It contributes to the empirical evidence for the correlation among the various types of accountability obligation and the work performance based on the institutional theory with mixed method, which is a quantitative approach with PLS and a qualitative approach with thematic analysis. Its samples are 201 SKPD officers in the local government of Nusa Tenggara TimurProvince. The results of the study show that the conflict in the accountability requirement has significant impact on the work context with negative perception at different levels, but does not have any significant impact on the work performance of the accountability actors.
\end{abstract}

Keywords: accountability, accountability requirements, work performance, and mixed method.

\section{INTRODUCTION}

The study is based on empirical phenomena in Indonesia since the issuance of the Presidential Instruction Number 7 of 1999 on Accountability Reporting of the Performance of Government Institutions (Instruksi Presiden No. 7 Tahun 1999 tentang Laporan Kinerja Instansi Pemerintah). The presidential instruction requires all government institutions to report their performance to the central government. In practice, this accountability is not as was expected. Some causal factors of the failure in fulfilling the expectation are the heterogeneity of the government institutions (Akbar et al., 2012), biased reporting (Solikin, 2005), and the tendency of local government to report successful programs and not to report failed programs (Nurkhamid, 2008).

From a different perspective, the failure in the implementation of the accountability program may be explained on the basis of the accountability concept itself. Accountability is perceived to be the obligation and the requirement to justify or to be accountable for all of the actions of the actors (Bovens, 1998) and an obligation to manage expectations of the accountability forum (Romzek \& Dubnick, 1987). The accountability concept in this context has not been studied in the government of Indonesia, but indications of the accountability concept are already observed in Indonesia. Akbar et al. (2012) suggests that the causal factor for the 
failure of the implementation of the accountability in the government of Indonesia is the pressure from the legislation obligation of the central government.

The model used in the study is based on the study by Kim \& Lee (2009) in the non-pofit sector. The accountability requirement forms used are hierarchical accountability, legal accountability, professional accountability and political accountability (Johnson \& Romzek, 1999) that have been used in the public sector. Each of these types of accountability indicates a different individual autonomy level and expectation source or control source, and has an impact on the differing work performance of the accountability actors. Use of a form of accountability based on source, namely accountability to, with political, legal, professional and hierarchical accountability, but no use of accountability for or the accountability based content, such as financial accountability and performance accountability, is reflected in the Indonesian government's accountability report. The basic reason is accountability for and accountability to are part of the integrative process. A different accountability for comes from a different accountability to (Yang, 2012). A further phenomenology description of accountability considers individual perceptions and their role in accountability (Tetlock, 1985). Perceptions of accountability, sometimes leading to felt accountability (Frink \& Klimoski, 1998), which is not only about the formal aspects of their work (what is written in the job description) but also informal aspects of their work (what authority do not required, but what the actors think about what they should be doing, provides such norms in the workplace).

This study uses SKPDs as an object of research. The reason SKPDs is used as an object is due to the role and function of SKPD's itself. $S K P D$ constituted a breakthrough from a centralistic government administration to a more balanced distribution of power, functions, and financial resources between central and local government and gave wide-ranging autonomy to the district and city governments. These conditions provided local governments with full au- thority in the planning-cycle process, and control over their finances (revenue and spending), civil services, and organisational setup (Podger \& Perwira, 2004). In their relationship with accountability, SKPD's hold an important function because of their accountability obligations to the stakeholders (Akbar, 2012).

This studies question is: does the conflict of the accountability requirement relate to the work performance of the accountability actors, if the conflict of the accountability requirement is perceived to be the workload and the work pressure on the accountability actors? The results of the study contribute to filling the gap in the prior studies. The results of the studies by Anechciaricho \& Jacobs (1994), Brody (2002), Dicke (2002), Ebrahim (2003), Halachmi et al. (2002), Jos \& Tompkins (2004), Koppell (2005), O'Connel (2006), Page (2004), Schwartz \& Zulitzeanu-Kenan (2004) suggest that the accountability requirement is negatively correlated to the performance of the accountability actors. The results of the studies by Caseley (2006), Kim (2005) and Wang (2002) suggest that the accountability requirement is positively correlated to the work performance of the accountability actors. Dubnick (2005) at the concept level shows that there is no correlation between the accountability types and the performance, and that it is necessary to broaden the perspective of the factor that relates the account giving and the performance. The results of the study are corroborated by the studies done by Dubnick \& Yang (2009), Kim \& Lee (2009) and Tetlock (1985) which suggest that the accountability requirement is correlated to the performance, depending on individual feeling involved in the accountability correlation. Subsequently, the study also contributes to the use of the design of the mixed method to fill the gap in the method of the prior studies and to include isomorphism phenomena in Indonesia. It also practically contributes to the discourse of the determination of proper accountability type in each of the local government institutions, their respective expectations, (Romzek \& Dubnick, 1987) and not merely a homogenization because of the legislation pressure by the central government (Akbar et al., 
2012). The results of the study show that the accountability requirement forms have a significant impact on the work context, with a negative perception at different levels, and a negative perception of the work context because the conflict of the accountability requirement does not have any significant impact on the work performance of the accountability actors. The results of hypotheses testing are corroborated by the results of in-depth interviews, especially in the phenomena of institutional isomorphism in the practice of local government.

The study is organized as follows: part 2 is the literature review and hypotheses formulation, part 3 is the study method and the description of data and samples of the study, study model and statistical instruments, and study variables, part 4 has the study results and discussion, and at the end conclusions, implications, limitations and recommendations for future studies are presented.

\section{THEORETICAL BASIS AND HYPOTHESES DEVELOPMENT}

\section{Institutional Theory}

In an institutional perspective, organizational legitimacy is an organizational existence basis. The legitimacy is a statement by the organization through the pattern of actions organized in its environment (DiMaggio \& Powell, 1983). Using structures and processes that consider legitimacy in the operating environment, an organization will seem to be responsible for satisfying its stakeholders and to avoid the negative impact of being blamed if mistakes take place (Meyer \& Rowan, 1977). Social legitimacy may be maintained by socially accepting normative and symbolic components and complying with institutional requirements of the external environment. Consequently, organizations operating in the same environment, such as local government, usually indicate a similarity in structure and practice. Similarity among organizations as a result of normative and cognitive processes is referred to as institutional isomorphism (DiMaggio \& Powell, 1983).

\section{Institutional Isomorphism}

According to DiMaggio \& Powell (1983) the main institutionalization outcome is homogeneous organizational structure. The organizations become homogenous in the same environment as a result of isomorphic forces. The change results from the homogenization process without any improvement in efficiency. The isomorphism is the organizational homogenization process in a given environment. Therefore, it is defined as a restraining process that forces a unit in a population to be similar with other units facing a set of similar environmental conditions (DiMaggio \& Powell, 1983). Institutional theory describes the homogenization process with three pressure forms, which are coercive, mimetic and normative.

\section{The Conflict of Accountability Requirement, Work Context and Work Performance}

Bovens (2005) defines accountability as a specific social relation or mechanism in which individuals feel required to explain and justify their behavior. The definition puts the emphasis on the meaning of the requirement among managerial agents that are consistent with the idea of their accountability (Bovens, 1998) and the management of expectations (Romzek \& Dubnick, 1987). Based on the definition, accountability consists of various types of relations and severs various interests. The behavior of a public institution is required to be accountable for the various types of forum in various manners.

The types of the accountability forum are reflected in the various types of accountability requirements. Johnston \& Romzek (1999) classify the types of the accountability requirements based on an individual autonomy level and expectation or control source into hierarchical accountability, legal accountability, professional accountability and political accountability. The effort to balance the accountability by the types of the forum in various manners becomes an unsolvable problem (Posner, 2000) because it causes accountability fragility that subsequently results in the failure to achieve set values (Kim \& Lee, 2009) and in dysfunctional accountability 
that causes the stagnation of service delivery (Caseley, 2006).

The results of the study by Tetlock (1985) using an experimental approach show that perceived accountability pressure has a significant impact on individual cognition and individual emotional statement. Dubnick \& Yang (2009) suggest that the correlation among various types and functions of accountability and their interaction have a significant impact on performance. They are corroborated by Kim \& Lee (2009) suggesting that the requirement for various types of accountability through perceived negative work context has a significant impact on the achievement of work performance. If legitimacy types and expectation are expressed as challenges for accountability actors, because of the uncertainty of which source should be considered first to each given situation (Romzek, 2000), the accountability actors consider the conflict of the accountability requirement as a workload. Meanwhile, the accountability actors involved in the role conflict (Fryet et al., 1986) cause psychological pressure in achieving certain performance levels. Therefore, the accountability actors perceive the conflict of the accountability requirements as work pressure. Kim \& Lee (2009) suggest that perceived workload and work pressure have different impacts on the work performance of the accountability actors depending on the perceived accountability requirements of the accountability actors.

\section{The Conflict of Accountability Requirements and Work Context}

Perceived hierarchical accountability, perceived workload and perceived work pressure

Coercive isomorphism is reflected in local government through the hierarchical accountability requirement, which is the strict supervision of individuals, with low working autonomy and internal controls that puts the emphasis on a command-like structure based on the compliance of subordinates to their supervisor (Romzek, 2000) through various organizational rules and regulations, directives and working standards (Kim \& Lee, 2009).
The hierarchical accountability pressure causes subordinates to spend more time achieving their supervisor's expectations and thus ignoring their main tasks in the organization (Kim \& Lee, 2009). According to Fry et al. (1986) their involvement in the role conflict causes psychological pressures to achieve certain expectations. Additionally, a low autonomy level causes powerless subordinates not to make tasking a priority (Hansen \& Host, 2012) and to respond to the condition as an extension of work, in the form of work accumulation and additional work (Houston et al., 2006). Based on the aforementioned theoretical background and arguments, the following hypotheses are formulated:

H1a: The hierarchical accountability requirement is positively correlated to workload.

H1b: The hierarchical accountability requirement is positively correlated to work pressure.

Perceived legal accountability, perceived workload and perceived work pressure

Legal accountability refers to the relationship between the accountability actor's compliance, and external supervision through strengthening the performance mandate, reflecting detailed external supervision of the accountability actor's performance that aims at regulating contractual relations. The external parties make the regulations and policies, while the accountability actors are required to implement them without any consideration of their knowledge and skills (Romzek \& Dubnick, 1977; Romzek \& Ingraham, 2000). In a local government context, the legal accountability reflects the coercive isomorphism taking place through the rules and legislation as the compliance form to the mandate giver, such as through Presidential Instruction Number 7 of 1999 on the Accountability Reporting of Government Institution Performance in which the implementation of the reporting does, in practice, not consider the heterogeneity of the local government (Akbar et al., 2012).

The lack of consideration for the skills and the knowledge of the accountability actors has a 
significant impact on the perceived workload because the accountability actors must achieve external expectations that do not always fit their capability and institutional needs (Romzek, 2000). The legal accountability requirement also has a significant impact on work pressure because the accountability actors perceive that they are outside the main organizational objectives to deliver public services, to pay altruistic attention and to comply with internal standards that put more emphasis on technical matters to meet the demands of the external regulations (Kim \& Lee, 2009). Based on the aforementioned theoretical background and argument, the following hypotheses are formulated:

H2a: The legal accountability requirement is positively correlated to workload.

$\mathrm{H} 2 \mathrm{~b}$ : The legal accountability requirement is positively correlated to work pressure.

Perceived professional accountability, perceived workload and perceived work pressure

Professional accountability is reflected in a working management with a high level of autonomy for individuals who make decisions based on the proper practical internalized norms. The professional accountability reflects normative isomorphism because the accountability actors are more influenced by internal values and norms than by politics, (Seldon et al., 1999) with the objective of achieving certain work performance levels consistent with the norms derived from professional socialization, personal belief, organizational culture and working experience, that subsequently enables them to make proper decisions, although there is no lead from supervisors nor regulatory requirements (Romzek, 2000).

The internalized norms are negatively correlated to the workload and work pressure, because the actors work following professional standards with high levels of autonomy to make expert decisions which are recognised by the higher autonomy (Kim \& Lee, 2009). Based on the aforementioned theoretical background and arguments, the following hypotheses are formulated:
H3a: The professional accountability requirement is negatively correlated to workload.

$\mathrm{H} 3 \mathrm{~b}$ : The professional accountability requirement is negatively correlated to work pressure.

Perceived political accountability, perceived workload and perceived work pressure

Political accountability gives the optional opportunity to accountability actors to concern themselves with various types of forums, such as society, media and legislative bodies. Its essence is in the responsibility of the accountability actors in responding to and anticipating the agenda and the expectation of the various types of forums that exceed the scope of supervisorsubordinate obligations or professional expertise (Romzek, 2000).

Direct accountability in local government to the people is formally substituted by their accountability to politicians as public representatives in parliament. Each organization has a different political emphasis depending on the relationship between the organization and the representatives (Akbar, 2011). Based on the concept of coercive isomorphism, one of the political accountability requirements is through development planning meetings or Musyawarah Perencanaan Pembangunan (Musrenbang) that are implemented by Act Number 25 of 2004 on the National Development Planning System (UU No. 25 Tahun 2004 tentang Sistem Perencanaan Pembangunan Nasional).

From the point of view of the SKPD, the Musrenbang process of joint discussions with the local assembly of the DPRD becomes a pressure on the $S K P D$, because it is more influenced by the ongoing political conditions, including the political relationship with the local government and the DPRD. The political accountability requirement has a significant impact on its workload because to meet the expectation exceeds its expertise limits and supervisor directives (Romzek, 2000). Additionally, political accountability has a significant impact on its work pressure because of the need to accomplish responsibilities which reflect its legitimacy is highly dependant on how well the actors an- 
ticipate and fulfill the expectations of the forum and whether the actors are perceived to be working partners (Romzek \& Ingraham, 2000). Based on the aforementioned theoretical background and arguments, these following hypotheses are formulated:

$\mathrm{H} 4 \mathrm{a}$ : The political accountability requirement is positively correlated to workload.

H4b: The political accountability requirement is positively correlated to work pressure.

\section{Work Context and Work Performance}

Perceived workload, perceived work pressure and perceived work performance

Accountability actors often face various types of authority legitimacy and performance expectation conflicts (Dubnick \& Romzek, 1991). Romzek (2000) suggests that the types of the legitimacy and expectation pose challenges to the accountability actors because they sporadically cause uncertainty about which source to consider first in each given situation. The accountability actors respond to them by accumulating work and additional work, and not in the form of adapted work (Houston et al., 2006). If various types of accountability requirement are perceived as an extension of work and there is no authority to determine the priority for the type of the accountability, the accountability actors will consider each type of accountability requirement that will impact on the work performance of the accountability actors as being the same (Kim \& Lee, 2009).

The implementation of the organizational administration function causes the weak role of the accountability actors (Kim \& Lee, 2009). Lyons (1971) suggests that the uncertainty in the expectation is closely related to individual pressure and performance. If the accountability actors are required to respond to the expectations of the forum with different ideas of the accountability and in a different condition (Brody, 2002; Ebrahim, 2003), it causes work pressure that has a significant impact on the performance because of the significant role of the accountability actors in fulfilling the expectation. This is consistent with the results of the study by Bedeian \& Armenakis (1981) which suggested that work pressure resulting from the willingness to achieve the work performance has a negative impact on the work performance. Based on the aforementioned theoretical background and arguments, these hypotheses are drawn:

H5a: The workload is negatively correlated to work performance.

$\mathrm{H} 5 \mathrm{~b}$ : Work pressure is negatively correlated to work performance.

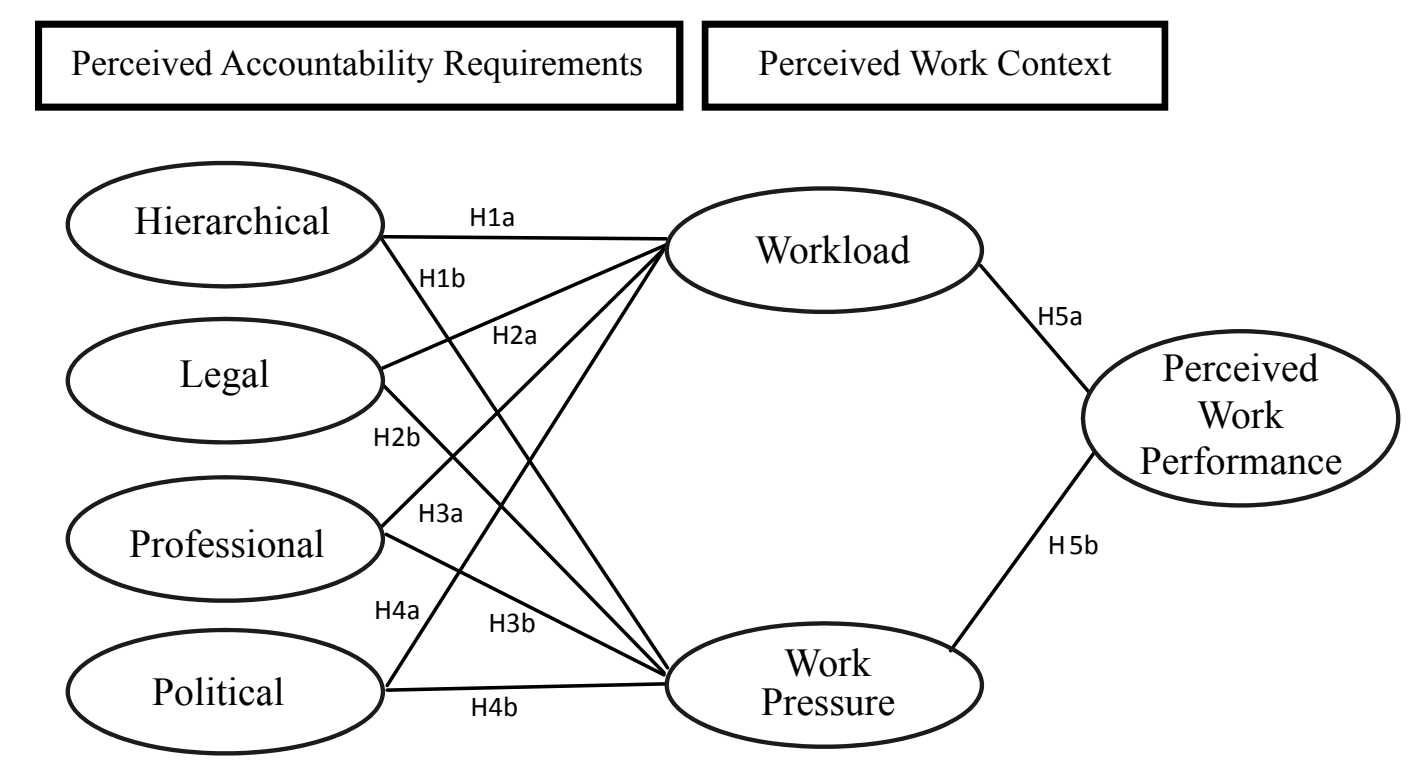

Figure 1. Research Model 


\section{RESEARCH METHOD}

This study uses a mixed method that combines a study technique, method, approach, concept or quantitative and qualitative languages into a single study. It uses explanatory and sequential strategies, which is a study method design in which the author begins by making a quantitative step followed by a qualitative step (Creswell \& Clark, 2011).

\section{Study Sample}

The study was conducted in Nusa Tenggara Timur Province. It looked at the local government institutions (i.e., bodies and offices). Its samples were drawn using purposive sampling. The criteria were SKPD's officers in each echelon that have been in the position for a minimum of a year, understand the condition of the SKPDs and were involved in the implementation of tasks and mandates. Selection criteria for the SKPDs for each local government were for SKPDs who were willing to be the object of the study, based on research from a covering letter distributed to all SKPDs in each local government. The cover letter contained specified criteria for respondents and for their willingness to become the object of our research. It was expected that respondents would be SKPDs that meet the criteria, while the criteria for the determination of the area of the study would be representative of the differences in administrative level (i.e., province, district and city) and the establishment time. It was expected that the results would reflect the differences in the accountability requirement pressure because of the difference in the accountability forum.

\section{Data Collection}

Data are collected using a survey technique for the quantitative approach and a semi-structured interview for the qualitative approach. The survey was conducted using a questionnaire distributed to the respondents. The qualitative approach was carried out through direct interviews with the respondents and aimed to grasp a deeper understanding of the existing phenomena. Examination of the results of the study from the different approaches and exploring the outlier and extreme results in the analysis of the quantitative data was our first step (Creswell \& Clark, 2011).

\section{Operational Definition and Variable Measurement}

Accountability requirement. The accountability requirement is defined as the working quality or performance level necessary for the accountability actors to achieve the expectations of the various types of accountability forums (Kim \& Lee, 2009), that is measured using the instruments developed by Kim \& Lee (2009), with the types of accountability requirement based on Jonston \& Romzek (1999), which are hierarchical accountability, legal accountability, professional accountability and political accountability.

Workload. The workload is the status of various problems and interests that are considered by individuals to be the same because of the existing working complexity (Hansen \& Host, 2012), that is measured using the measurement instrument of index of organizational reaction developed by Smith (1976).

Work pressure. The work pressure refers to the condition of an individual's psychological anxiety as a consequence of their significant role in trying to achieve a certain working quality or performance (Bedeian \& Armenakis, 1981) with the impact of role conflict or role uncertainty (Fry et al., 1986) that is measured using the tension index developed by Lyons (1971).

Work performance. The work performance refers to the skills or the capability of actors to conduct formal activities and accept, as part of the working activities, that they have a direct and indirect contribution (London \& Sminther, 1997). The measurement of the work performance is carried out using the measurement system developed by Tsui et al. (1997).

\section{Data Analysis Method}

Hypotheses are tested using a partial least square (PLS) analysis instrument. The PLS is structural equation modeling (SEM) based on variants that are simultaneously able to test the 
measurement model and structural model (Hartono, 2011). The qualitative approach is carried out using a thematic analysis of the interview transcriptions. The thematic analysis represents a qualitative analysis method to identify, analyze and to report patterns (themes) of data (Braun \& Clarke, 2006). Subsequently, the separated data resulting from the interviews can be connected to the problems of the study and the data is interpreted in the form of the description of results (Aronson, 1994).

\section{Analyses and the Discussion of the Results Quantitative Analysis}

Pilot study

Respondents to the pilot study were 34 officers in Dinas Kelautan dan Perikanan Provinsi Daerah Istimewa Yogyakarta. The analysis of the pilot study was made using the smartPLS 2.0 and it gave 33 indicators (of the total number of 42 indicators) that met the requirements with an AVE value and communality $>0.5$. The composite reliability was $>0.6$ for each variable. The results showed that the questions in the study were valid and reliable, and that they are reasonable for further use.

\section{Quantitative Data Collection}

Quantitative data were collected through the survey of 70 SKPDs in East Nusa Tenggara, including offices, agencies and bodies. There were 113 SKPDs who had our covering letter sent to them (in Kabupaten Kupang: 38, Kota Kupang: 34, Provinsi Nusa Tenggara Timur: 41) and 43 of them chose not to respond to us (38.1\%). Five questionnaires were submitted to each echelon of the SKPDs, a total of 350 questionnaires, and 239 of them $(68.3 \%)$ were returned, of which 201 are eligible for use (57.4\%). The respondents profiles are presented in Table 1.

\section{Demographic Analysis}

The results of the demographic analysis using ANOVA indicates that the demographic factors do not have any significant impact on the exogenous and endogenous constructs. The impact of the demographic factor of gender on performance is 0.471 , on workload 0.205 and work pressure 0.333 . The impact of the demographic factor of age on performance is 0.499 , on workload 0.588 and on work pressure 0.122 . The impact of the demographic factor of education level on each of the work performance constructs, workload, and work pressure is

Table 1. Profile of Respondents

\begin{tabular}{lllclc}
\hline \multicolumn{1}{c}{ Notes } & Number & \multicolumn{1}{c}{$(\%)$} & Notes & Number & $(\%)$ \\
\hline Gender: & & & & & \\
Male & 105 & $52,24 \%$ & Length of Service: & & \\
Female & 96 & $47,76 \%$ & $>10$ years & 74 & $36,82 \%$ \\
& 201 & $100 \%$ & $10,1-20$ years & 102 & $50,75 \%$ \\
Age: & & & $>20$ years & 25 & $12,44 \%$ \\
$<30$ years old & 12 & $5,97 \%$ & & 201 & $100 \%$ \\
$31-40$ years old & 21 & $10,45 \%$ & Echelon: & & \\
$41-50$ years old & 115 & $57,21 \%$ & IV & 105 & $52,24 \%$ \\
$>50$ years old & 53 & $26,37 \%$ & III & 68 & $33,83 \%$ \\
& 201 & $100 \%$ & II & 5 & $2,49 \%$ \\
Education: & & & Others & 23 & $11,44 \%$ \\
SMA & 6 & $2,99 \%$ & & 201 & $100 \%$ \\
D3 & 15 & $7,46 \%$ & & & \\
S1 & 148 & $73,63 \%$ & & & \\
S2 & 32 & $15,92 \%$ & & & \\
& 201 & $100 \%$ & & & \\
\hline
\end{tabular}


$0.982,0.939$ and 0.329 , respectively. The demographic factor for working period shows a significance of 0.828 for work performance, 0.289 for workload, and 0.159 for work pressure. The demographic factor of echelon for work performance construct is 0.944 , workload 0.091 and work pressure 0.186 .

\section{Non-response bias}

The test for non-response bias caused by location was carried out in the study because the area of the study was wide enough. A Kruskal Wallis test was carried out to make sure that there was not any inter-regional difference, including a non-parametric test to simultaneously compare three data groups (Supangat, 2007) with SPSS 16.0. The results show that there is not any inter-regional difference in the samples of the study. The Kruskal Wallis test gives the following results for each area: Kupang district $(n=73)$, Kupang City $(n=71)$ and East Nusa Tenggara province $(n=57)$ at a significance of $>0.05$. Hierarchical accountability construct $(\mathrm{t}=0.489)$, legal accountability construct $(\mathrm{t}=0.219)$, professional accountability construct $(\mathrm{t}=0.274)$, political accountability construct $(\mathrm{t}=0.125)$, workload construct $(\mathrm{t}=0.730)$ and work pressure construct $(\mathrm{t}=0.465)$.

\section{Hypotheses Test}

The measurement model analysis with the PLS algorithm iteration gives validity and reliability test results. The validity test consists of convergent validity through AVE score and communality with criteria $>0.5$ and discriminant validity through a cross lading score with criteria $>0$, but the score 0.5-0.7 is still acceptable if the AVE $>0.5$ (Hair, 2010). The reliability test may be seen in the composite reliability score with criteria $>0.6$. Table 2 summarizes the results of the algorithm iteration showing that the study instrument is considered to be valid and reliable because they have met validity and reliability criteria.

Structural modal was evaluated using $R^{2}$ for the dependent construct. It is clearly observed from table 4.5 that the $R^{2}$ value for the construct of workload (WL) is 0.25834 , the construct of work pressure (WP) is 0.096907 , and the construct of work performance (WPer) is 0.131151 . The results mean that the proposed study model can explain the construct variable of workload, which is $25 \%$, the construct of work pressure $9 \%$, the construct of work performance $13 \%$, and the remaining is explained by other variables outside the proposed model.

The hypotheses test was conducted through the structural model test by comparing the $\mathrm{T}$-statistic value and T-table value. The results of the test with bootstrapping summarized in table 4 show that hierarchical accountability hypothesis (H_1a) is empirically confirmed (HA- $>$ WL: $\gamma 1=0.3520, t=3.5733)$. The legal accountability hypothesis $\left(\mathrm{H} \_2 \mathrm{a}\right)$ is empirically confirmed (LA$>$ WL: $\gamma 1=0.2240, \mathrm{t}=2.8328$ ). The professional accountability hypotheses (H_3a H_3b) is empirically confirmed (PA-> WL: $\gamma 1=-0.1595$, $\mathrm{t}=1.8194$; PA-> WP: $\gamma 1=-0.3389, \mathrm{t}=3.8923)$. The political accountability hypotheses (H_4b) is empirically confirmed (POA-> WP: $\gamma 1=0.1839$, $\mathrm{t}=1.7974)$. The hypotheses confirmation takes place at $\mathrm{t}->1.64, \mathrm{P}<0.05)$ and $\mathrm{t}>2.33, \mathrm{P}<0.01$ (one tailed), while H_1b (HA->WP: $\gamma 1=-0.0246$, $\mathrm{t}=0.1921), \quad$ H_2b $\quad$ (LA->WP: $\quad \gamma 1=0.1145$, $\mathrm{t}=0.9916), \quad$ H_4a $\quad($ POA- $>\quad W L: \quad \gamma 1=0.1085$, $\mathrm{t}=0.15549), \quad \bar{H} 5 \mathrm{~b} \quad$ (WP->WPer: $\gamma 1=-0.1479$, $\mathrm{t}=1.4006)$ are not empirically confirmed because the T-statistic value is lower than the T-table value (1.64), while $\mathrm{H}$-5a shows that the perceived workload has a positive impact on the accountability actor performance (WL->WPer: $\gamma 1=0.3363, \mathrm{t}=4.1582$ ) and that H_5a is empirically not confirmed. The results show that the conflict of the accountability requirement has a significant impact on the perceived work context of the accountability actors at different levels, depending on individual feeling involved in the accountability, which means how the individuals perceived the correlation between the accountability pressure and the interaction of the accountability pressure (Dubnick and Yang, 2009). In general, the results of the hypotheses test are summarized in table 2 . 
Table 2. Overview Iteration Algorithm PLS

\begin{tabular}{lcccccc}
\hline & \multicolumn{2}{c}{ Validity Test } & & \multicolumn{2}{c}{ Reliability Test } & \multirow{2}{*}{ R Square } \\
\cline { 2 - 3 } \cline { 5 - 6 } & AVE & Commu-nality & & Cronbac-hs Alpha & Composite Reliability & \\
\hline Hierarchical & 0.525174 & 0.525174 & & 0.772317 & 0.845316 & \\
Legal & 0.650023 & 0.650023 & & 0.891266 & 0.917258 & \\
Professional & 0.557016 & 0.557016 & & 0.803813 & 0.861738 & \\
Political & 0.582019 & 0.582019 & & 0.857721 & 0.892484 & \\
Workload & 0.751214 & 0.751214 & & 0.831835 & 0.900072 & 0.258534 \\
Work Pressure & 0.511044 & 0.511044 & & 0.755239 & 0.836443 & 0.096907 \\
Work Performance & 0.537555 & 0.537554 & & 0.588128 & 0.771875 & 0.131151 \\
\hline
\end{tabular}

\section{Qualitative Analysis}

\section{Qualitative data collection}

The selection of the respondents to interview was conducted on the basis of the results of the quantitative data processing and some criteria such as outlier respondents only, the availability of the respondents to be interviewed, as shown in the interview availability sheet in the questionnaire, and the representation of the area of study that was expected to represent the population. Here is the spread of the results of the quantitative data processing indicating that the outlier data is found using scatter plot analysis (Figure 2).

It is clearly observed in figure 2 that six respondents were selected for the interview. There are only three respondents in the study selected for the interview and represent the three areas and the respondents with an outlier response at the upper limit. They are likely to respond to Likert scale 4 and 5 . The interview was carried out by a face-to-face interaction for sixty minutes on average. The results of the interview were recorded using an audio recorder, once it was agreed to by the respondents.

\section{Qualitative data analysis}

Qualitative analysis aims at supporting and describing more clearly the results of the quantitative data processing. It uses a narrative approach in describing the collected qualitative data. It also aims at including institutional isomorphism phenomena, which is coercive isomorphism through hierarchical, legal, political and professional accountability requirements as described through the normative isomorphism concept.

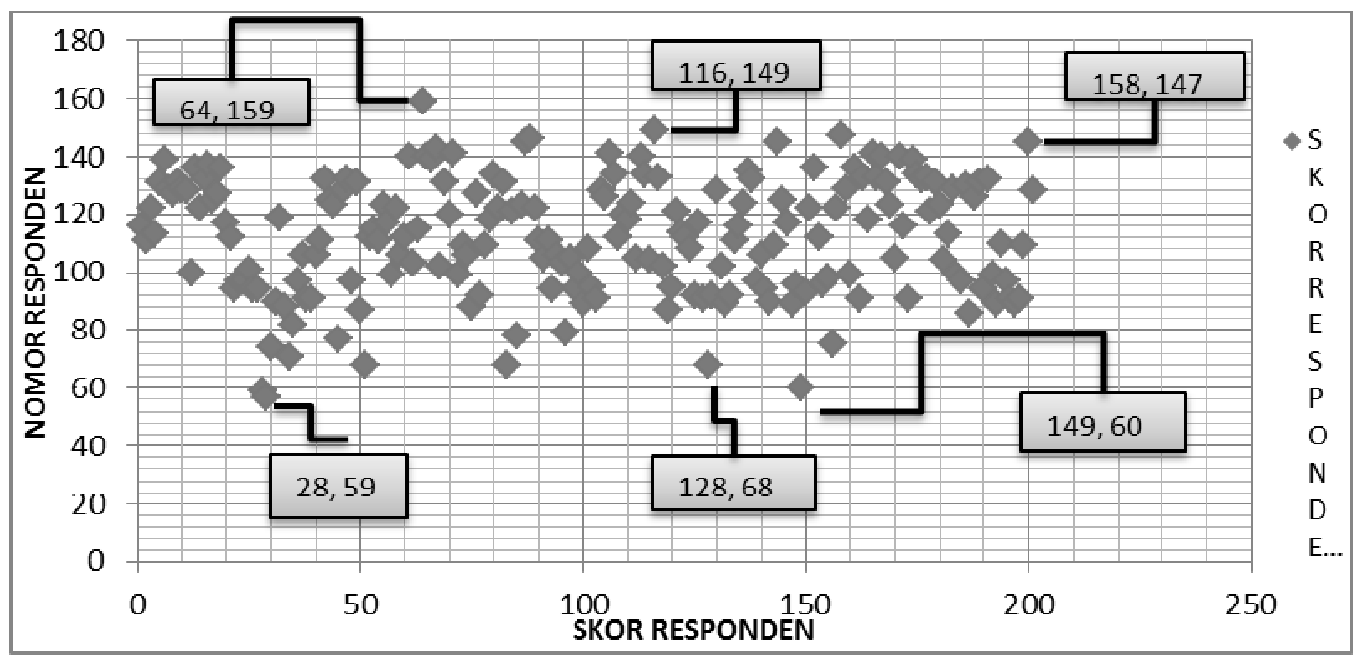

Figure 2. Scatter Plot 
The conflict of accountability requirement

Based on the content analysis of the interview transcriptions, it may be concluded that according to Jonston \& Romzek (1999) hierarchical, legal, professional and political accountabilities take place in the context of local government. Here is a quote from one of the interviews:

Accountability is the responsibility method we used to maintain the people's and central government's trust. I mean, it is an instrument for us, local government, such as Public Works to report the results of our work to the people and the central government ... Indeed, I have to be responsible to my supervisors because the system requires me to be responsible to them and also to myself.

(Kasubag Keuangan

Dinas PU Provinsi NTT)

The coercive isomorphism phenomena is reflected through the hierarchical accountability as expressed below.

Personally, I understand that I am officer of the office who works in a standard system. What I do has a certain impact on my superior's evaluation of me. For one simple example, the authority of superior to sign DP3 ...

(Kasubag Program, Evaluasi dan Perencanaan Dinas Perhubungan Kota Kupang)

The coercive isomorphism phenomena through the legal accountability is reflected in the following interview result:

Central government requires us to prepare the same accountability report. Sometimes, we do not understand and do not know what we have to report. Avoiding mistakes, we follow the rule....

(Kasubag Program, Evaluasi dan Perencanaan Dinas Perhubungan Kota Kupang)

The same opinion is reflected in the following interview:

Yes. I have to say that. There is an impression that the accountability is forced onto us. It is not a big obstacle for a big office with sufficient human resource, but it is a serious difficulty for us here in Dinas Kelautan dan Perikanan ...

(Sekdin Kelautan dan Perikanan

Kabupaten Kupang)

The coercive isomorphism phenomena through political accountability is reflected in the following interview result:

But, when the results are submitted to the local assembly, it must be admitted that what plays a role is not what should be, but how the government does lobbying. ...

(Sekdin Kelautan dan Perikanan Kabupaten Kupang)

The normative isomorphism phenomena through professional accountability is reflected in the following interview result:

I am assigned to certain area and hence I am indirectly considered to be able to work in that area ... Professionalism becomes a filter so that I am kept in the right line. I try to put the professionalism side by side with other responsibilities ....

(Kasubag Keuangan Dinas PU Provinsi NTT)

Perceived negative work context resulting from the conflict of accountability requirement

Based on the results of the quantitative data processing, the accountability requirement forms have a significant impact on the condition of various interests that must be treated equally by individuals because of the work complexity. It is reflected in the following interview result:

That is the fact. There are many people or bodies to which we have to be accountable. Sometimes, it is simply confusing. They are the ones to which we have to be accountable, but they evaluate us the way they want and sometimes we put priority on one responsibility over the others.

(Kasubag Program, Evaluasi dan Perencanaan Dinas Perhubungan Kota Kupang)

The opinion is confirmed by the following interview result:

That must be acknowledged. I need more time to accomplish them though they (work pressures) go side by side, but the amount of 
work increases. Therefore, I spend more time...

(Sekdin Kelautan dan Perikanan Kabupaten Kupang)

The types of the accountability requirement also have a significant impact on the psychological anxiety of individuals as the consequence of the significant role in achieving a certain working quality as a result of the conflict of roles. The condition is reflected in the following interview result:

There must be obstacles. There are many heads (parties) with many demands. Finally, all of them must be evaluated. The obstacles of time, capability and other obstacles ... If it relates to workload or pressure, I think it may take place ... If there are many demands, the amount of work increases.

(Kasubag Keuangan Dinas PU Provinsi NTT)

The Working Criteria Resulting from the Perceived Negative Work context of the Conflict of Accountability Requirement

The results of the hypotheses test show that the ability of the accountability actors in accomplishing their working activities, in the form of services, is not influenced by the work pressure because of the accountability conflict, while the workload has a positive impact on the performance of the accountability actors. The condition is reflected in the following interview results:

Up to the present there has not been any standard evaluation ... Performance still depends on whether a work has been in completion or not and not on time, but on final result ...

(Kasubag Program, Evaluasi dan Perencanaan Dinas Perhubungan Kota Kupang)

I think there is not any bad impact. All of the requirements are fulfilled and it means good performance. One thing to remember is that if we are given some responsibilities, it may be considered as a trust given to us.

(Kasubag Keuangan Dinas PU Provinsi

NTT)
Subsequently, the interview results show that in the context of the local government of the East Nusa Tenggara province, mimetic isomorphism phenomena takes place as reflected in the following interview result:

... for example, LAKIP. All of the offices are considered to be equal in evaluation. Accommodating it, the offices send their officers to other offices in East Nusa Tenggara or outside the province to learn about their success, and even try adopting their successful programs in the province. We still follow the existing standard....

(Kasubag Keuangan Dinas PU Provinsi NTT)

The same opinion is also expressed in the following interview:

There is an impression that accountability is forced onto us. All of the reporting forms have been standardized and all we must do is fill out the form, but there is the biggest problem. We keep learning to do the right things. We make use of the available examples and adapt them to our needs.

(Sekdin Kelautan dan Perikanan Kabupaten Kupang)

\section{CONCLUSIONS, IMPLICATIONS AND LIMITATIONS}

\section{Conclusions}

The results of the quantitative data processing with the strip coefficient analysis shows that the work performance of the accountability actors is negatively correlated to the work pressure, while the workload can increase the work performance of the accountability actors. The perceived workload and the work pressure are positively influenced by the conflict of accountability requirement at different levels depending on individual perception, while the professional accountability requirement can serve as the filter in balancing other conflict forms of the accountability requirement.

The results of the qualitative data processing confirm the results of the quantitative data processing and better grasp the coercive isomorphism phenomena in the form of legal, hierarchical and political accountability. The normative isomorphism phenomena are reflected in the 
form of professional accountability. Subsequently, the interview results show that there are mimetic isomorphism phenomena, especially through LAKIP, which in the study is considered as a coercive isomorphism.

\section{Implications}

The results of the study give inputs to the SKPD in the local government of the accountability conflict as a result of the requirements for various types of accountability. The consequence for the government institutions is that they operate in a given environment through the accountability requirement, and it is inefficient but tends to operate for public legitimacy. Also, they implicate in the policy making, that considering the heterogeneity of the accountability actors in making the policy and the regulations that require the accountability actors to be responsible for their accountability.

\section{Study Limitation and Recommendation for Future Study}

This study of the conflict of the accountability requirement and its impact on the work performance is the first study in Indonesia. Prior studies have been conducted on non-profit organizations outside of the government have had limitations that will influence the variable of the study. Firstly, the instrument used in the study for the work pressure and the work performance is eliminated because of a low cross loading. Further studies can examine the use of different instruments that fit the context of the studies. Secondly, the $R^{2}$ of the variable of the work pressure is 0.096907 , so that the model of the study can explain the variable of the workload, which is $9 \%$. According to Santosa et al. (2005) and Hanlon (2001) the minimum $R^{2}$ is $0.10(10 \%)$. Future studies can examine other variables. Thirdly, the quantitative step is based on the scatter plot analysis of the 6 outlier respondents. However, it is evidenced that there is a tendency for the same response, because the respondents gave their response at the upper limit of the actual range, or in Likert scale 4 and 5. Fourthly, the study at the quantitative step of the three study locations of the Kupang district government, Kupang City government and the government of the East Nusa Tenggara province used 201 respondents coming from 70 agencis, bodies and offices. Meanwhile, the East Nusa Tenggara province consists of 21 districts/cities. This condition indicates a low generalization for the scope of the province. Future studies can broaden their area of study or use the samples from other local government or non-profit organizations, using different forms of accountability. Mardiasmo (2009); Sinclair (1995); Romzek dan Dubnick (1987), test the direct effect of conflicting accountability requirements and performance (Dubnick, 2005), using other variabels to connect them (Tetlock, 1985), and using regression analysis to examine the influence between the variables.

\section{REFERENCES}

Akbar, R., Pilcher, R., \& Perrin, B. (2012). Performance Measurement in Indonesia: the Case of Local Government. Pacific Accounting Review, 262-291.

Anechiarico, F., \& Jacobs, J. B. (1994). Visionof Corruption Control and the Evolution of American Public Adminstration . Public Adminstration Review, 54(5), 465-473.

Bedeian, A. G., \& Armenakis, A. A. (1981). A Path-Analytic Study of the Consequences of Role Conflict and Ambiquity. The Academy of Management Journal, 417-424.

Bovens, M. (1998). The Quest of Responsibility. (2005). Two Concept of Accountability. The Oxford Handbook of Public Management, 182-208.

Braun, V., \& Clarke, V. (2006). Using Thematic Analysis in Psychology. Qualitative Research in Psychology, 3 (2), 77-10.

Brody, E. (2002). Accountability and public trust. Adminstration and Society.

Caseley, J. (2006). Multiple Accountability Relationship and Improved Service Delivery Performance in Hyderabad City, Southern India. International Review of Admnistrative Sciences, 531-546.

Creswell, J. W., \& Clark, F. L. (2011). Designing and Conducting Mixed Methods Research . Thousand Oaks, California: Sage Publications, Inc. 
Dicke, L. (2002). Ensuring Accountability in Human Service Contracting. Public Productivity \& Management Review, 22:502-516.

DiMaggio, P., \& Powell, W. (1983). The Iron Cage Revisited: Institutional Isomorphism and Collective Rationally in Organizational Field. American Sociological Review, Vol. 48: 147-160.

Dubnick, M. (2005). Accountability and the Promise of Performance. Public Performance \& Management Review, 28, 236-267.

Dubnick, M. J., \& Romzek, B. Z. (1991). Politics and the Management of Expectation. American Public Administration, New York, MAcmillan.

Dubnick, M., \& Yang, K. (2009). The Pursuit of Accountability: Promise, Problems, and Prospects. American Society for Public Administration Annual Conference (pp. 132). Armonk, New York: M. E. Sharpe.

Ebrahim, A. (2003). Making sense of accountability: Conceptual perspectives for Northern and Southern nonprofits. The American Review of Public Adminstration.

Fry, L., Futrell, C., Parasuraman, A., \& Chmielewski, M. (1986). An Analysis of Alternative Causal Models of Salesperson Role Percetion and Work-Related Attitudes. Journal of Marketing Research, 153-163.

Halachmi, A. (2002). A brief note on the methodology of measuring productivity of services at the local level. International Journal of Organization Theory and Behavior, 215-218.

Hansen, J. R., \& Host, V. (2012). Understanding the Relationship Between Decentralization Organizational Decesion Structure, Job Context, and Job Satisfaction-A Survey of Danish Public Managers. Review of Public Personell Administration, 32(2) 288-308.

Hartono, J. (2011). Konsep dan Aplikasi Structural Equation Modeling berbasiskan varian dalam penelitian bisnis. Yogyakarta: STIM YKPN .

Houston, D., Meyer, L. H., \& Paewai, S. (2006). Academics Staff Workload and Job Satisfaction: Expectation and Values in Academe. Journal of Higher Education Policy and Management, 17-30. (n.d.). Instruksi Presiden, Nomor 7 Tahun1999 Laporan Akuntabilitas Kinerja Institusi Pemerintah.

Johnston, J., \& Romzek, B. (1999). Contracting and accountability in state Medicaid reform: Rhetoric, theories, and reality. Public Administration Review, 59, 383-399.

Jos, P., \& Tompkins, M. (2004). The Accountability Paradox in an Age of Reinvention. Administration and Society, 36, 255-281.

Kim, S. E. (2005). Balancing competing accountability requirements. Public Performance \& Management Review, 29, 145-163.

Kim, S. E., \& Lee, J. W. (2009). Impact of Competing Accountability Requirements on Perceived Work Performance. The American Review of Public Administration, 100-118.

Koppell, J. (2005). Pathologies of accountability. Public Administration Review, 65, 94-108.

London, M., \& Sminther, J. W. (1997). Accountability: The Achilles' Heel of Multisource Fedback. Group and Organization Management, 22, 162-185.

Lyons, T. F. (1971). Role Clarity, Need for Clarity, Satisfaction, Tension, and Withdrawal. Organizational Behavior and Human Performance, 99-110.

Mardiasmo. (2009). Akuntansi Sektor Publik. Yogyakarta: Andi Offset.

Meyer, J. W., \& Rowan, B. (1977). Institutionalized Organizations: Formal Structure as Myth and Ceremony. American Journal of Sociology, 340:363.

Nurkhamid, M. (2008). Implementasi Inovasi Sistem Pengukuran Kinerja Instansi Pemerintah. Jurnal Akuntansi Pemerintah, 45-76.

O'Connell, L. (2006). Emergent Accountability in state-Local Relation: Some Lessons from Solid Waste Policy in Kentucky. Andminstration and Society, 38, 500-515.

Page, S. (2004). Measuring Accountability for Result in Interagency Collaboratives. Public Adminstration Review, 64, 591-606.

Posner, P. (2000). Accountability challenges of third-part government. Oxford, UK: Oxford University Press. 
Romzek, B. (2000). Dynamics of Public Sector Accountability in Era of Reform. International Review of Administrative Science, 21-44.

Romzek, B. S., \& Ingraham, P. (2000). Cross pressures of accountability: Initiative, command, and failure in the Ron Brown plane crash. Public Administration Review, 60, 240-253.

Romzek, B., \& Dubnick, M. (1987). Accountability in the Public Sector: Lesson from the Chalengger Tragedy. Public Admistration Review, 47, 227-238.

Schwartz, R., \& Sulitzeanu-Kenan, R. (2004). Managerial Values and Accountability in Pressures: Challenges of Crisis and Disaster. Journal of Public Adminstration Research and Theory, 14, 79-102.

Seldon, S. C., Brewer, G. A., \& Brudney, J. L. (1999). Reconciling Competing Values in Public Adminstration: Understanding the Admnistrative Role Concept. Admnistration and Society, 31(2) 17-30.
Sinclair, A. (1995). The Chameleon of Accountability: Forms and discourses. Accounting, Organizations and Society, 219-237.

Smith, F. J. (1976). Index of Organizational Reaction (IOR). JSAS Catalog of Selection Documents in Psychology.

Solikin, A. (2005). Accountability Reporting in Indonesia: When Self-Serving Attributions Exaggerate Perceived Performance. Jurnal Akuntansi Pemerintah, 21-33.

Tetlock, P. (1985). A Social Check on the Fundamental Attribution Error. Social Psychology Quarterly, 227-236.

Tsui, A., Pearce, J. L., Porter, L. W., \& Tripoli, A. M. (1997). Alternative Approachess to Employee-organization relationship: Does Investment in employees Pay off. Academy of Management Journal, 40(5)1089-1022.

Wang, X. (2002). Assesing Administrative Accountability: Result from a National Survey. American Review of Public Administration, 32, 350-370. 


\section{APPENDIX: RESEARCH QUESTIONNAIRE}

\section{Part 1}

\section{ACCOUNTABILITY REQUIREMENT CONFLICT}

$$
\begin{aligned}
& \text { Please, fill the columns of each row! } \\
& 1=\text { never } \quad 3=\text { rarely } \quad 3=\text { occasionally } \quad 4=\text { often } \quad 5=\text { always }
\end{aligned}
$$

Please, indicate the frequency with which you are involved in the following activities/works!

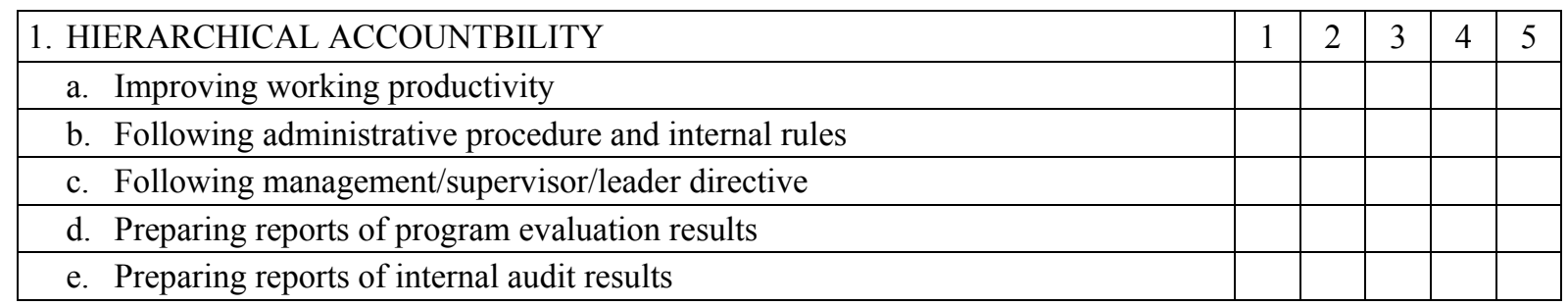

\begin{tabular}{|c|c|c|c|c|c|}
\hline 3. PROFESSIONAL ACCOUNTABILITY & 1 & 2 & 3 & 4 & 5 \\
\hline a. Following professional ethic codes & & & & & \\
\hline b. Giving dedication to organizational mission & & & & & \\
\hline c. Attending training, courses, carrier path, and profession conception & & & & & \\
\hline d. Improving service quality and best practices & & & & & \\
\hline e. Making decisions for the organization using knowledge and expertise & & & & & \\
\hline f. Observing the ethical policies of the office concerning service delivery & & & & & \\
\hline
\end{tabular}

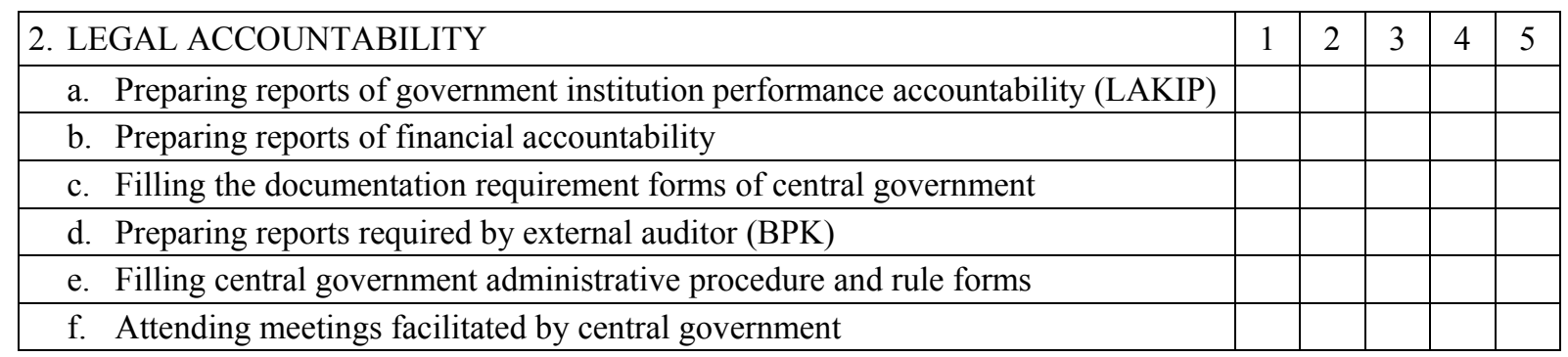

\begin{tabular}{|c|c|c|c|c|c|}
\hline 4. POLITICAL ACCOUNTABILITY & 1 & 2 & 3 & 4 & 5 \\
\hline $\begin{array}{l}\text { a. Meeting with local assembly (DPRD) members for public hearing (hearing } \\
\text { public aspirations) }\end{array}$ & & & & & \\
\hline $\begin{array}{l}\text { b. Being responsible for fulfilling local assembly's (DPRD's) expectations in terms } \\
\text { of finance and performance }\end{array}$ & & & & & \\
\hline c. Cooperating with local assembly (DPRD) in making policis and programs & & & & & \\
\hline $\begin{array}{l}\text { d. Implementing the decisions that have been made along with local assembly } \\
\text { (DPRD) }\end{array}$ & & & & & \\
\hline e. Maintaining a good relationship with the local media & & & & & \\
\hline $\begin{array}{l}\text { f. Reporting working results through the media (internet, television, radio and } \\
\text { newspaper) }\end{array}$ & & & & & \\
\hline
\end{tabular}




\section{Part 2}

\section{WORKLOAD}

Please, fill in the column to the left of the statements

a. I feel my work is:

\begin{tabular}{|l|ll|}
\hline & $1 . \quad$ Never to much \\
\hline & 2. & Rarely to much \\
\hline & $3 . \quad$ Occasionally to much \\
\hline & 4. $\quad$ Often to much \\
\hline & 5. $\quad$ Almost always to much \\
\hline
\end{tabular}

b. How does your expected number of works influence the way you do them?

\begin{tabular}{|l|ll|}
\hline & 1. & The amount of work almost always causes me to do the work well. \\
\hline & 2. & The amount of work often causes me to do the work well. \\
\hline & 3. & The amount of work does not influence me to do the work well. \\
\hline & 4. & The amount of work causes me rarely to do the work well. \\
\hline & 5. & The amount of work causes me never to do the work well. \\
\hline
\end{tabular}

c. What is your feeling about the amount of work you are expected to do?

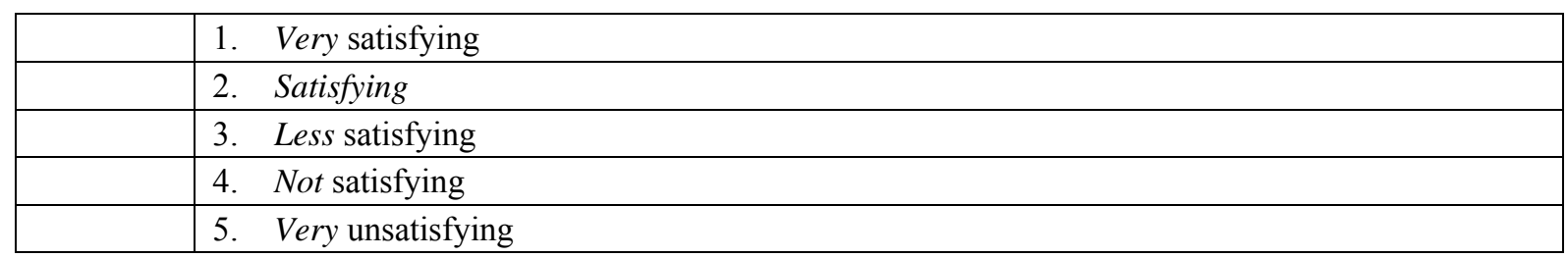

\section{WORK PRESSURE}

Please, fill the columns of each row!

$$
1=\text { never } \quad 3 \text { =rarely } \quad \text { =ccasionally } \quad 4=\text { often } \quad \text { always }
$$

Please, indicate the frequency you experience psychological anxiety because of your work!

\begin{tabular}{|c|c|c|c|c|c|}
\hline & 1 & 2 & 3 & 4 & 5 \\
\hline 1. I am not sure how broad my tasks and responsibilities are. & & & & & \\
\hline $\begin{array}{l}\text { 2. I do not know what my supervisors think of me, and how they evaluate my } \\
\text { performance. }\end{array}$ & & & & & \\
\hline 3. In fact, I do not get any information necessary to do my work. & & & & & \\
\hline 4. I do not know what the people who cooperate with me expect of me. & & & & & \\
\hline 5. I feel I get too big a working load and I cannot normally do some of it. & & & & & \\
\hline $\begin{array}{l}\text { 6. I think that the amount of work i'm given is determined by how well I } \\
\text { complete it. }\end{array}$ & & & & & \\
\hline 7. I feel what I have to do to in my work is contrary to my personal opinion. & & & & & \\
\hline 8. I feel I am not able to fulfill the requirements of various parties around me. & & & & & \\
\hline
\end{tabular}




\section{Part 3}

\section{WORK PERFORMANCE}

Please, fill the columns of each row!

$$
1=\text { never } \quad 3=\text { rarely } \quad 3 \text { occasionally } \quad 4=\text { often } \quad 5=\text { always }
$$

Please, indicate the frequency that you do work that contributes to the completion of a job!

\begin{tabular}{|l|l|l|l|l|l|}
\hline & 1 & 2 & 3 & 4 & 5 \\
\hline 1. I spend more time to complete my work on time. & & & & & \\
\hline 2. I pay full attention to important details. & & & & & \\
\hline 3. I work harder than I should. & & & & & \\
\hline 4. I ask to be assigned things. & & & & & \\
\hline 5. I train myself to be disciplined and self-controlled. & & & & \\
\hline $6 . \quad$ I take the initiative to solve problems in completing a job. & & & & \\
\hline 7. I have the perseverance to face challenges and complete a task. & & & & & \\
\hline 8. I am highly motivated to complete difficult tasks. & & & & \\
\hline
\end{tabular}

